\title{
An Experiment To Assess The Learning Benefits Of Employing Accounting Software In The Classroom
}

Brendan O'Connell, Ph.D., CPA, CMA, ASIA (Email: oconnell@ deakin.edu.au), Deakin University, Australia Ian Beaman (Email: Ian.Beaman@BusEco.monash.edu.au), Monash University, Australia

Paul de Lange (Email: Paul.Delange@BusEco.monash.edu.au), Monash University, Australia Kosmas Smyrnios (Email: kosmas.smyrnios@rmit.edu.au), RMIT University, Australia

\begin{abstract}
This paper reports on an experiment analysing the development of students' understanding of accounting concepts by comparing three different teaching strategies: a traditional tutorial (workshop), exposure to a commercial accounting package, and a control group. Findings indicate that integration of a commercially available accounting package into accounting curricula does not significantly enhance students' understanding of accounting concepts. As this experiment employed a randomised allocation of students to groups, a control group, and identical pre and posttests, these findings are robust to alternative explanations such as learning styles and motivation.
\end{abstract}

\section{Introduction}

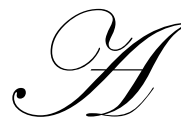

ccounting education has been revolutionised by the introduction of computer technology into learning. This evolution in accounting education has been precipitated by calls from educators (e.g., Albrecht \& Sack, 2000; American Education Change Commission (AECC), 1990; Bedford Committee, 1986), and by practitioners (e.g., Institute of Chartered Accountants in Australia (ICAA), 1994) who have recognised the importance of information technology to the role of accountants in the $21^{\text {st }}$. Century. Recognising that educators play a pivotal role in training future accountants, universities have responded to these calls by integrating information technology into courses (Suwardy \& De Lange, 1998). This introduction of computers into accounting curricula can be dissected into 3 major categories: teaching machines (often termed computer-aided instruction, for example, McKeown, 1976; Paterson, 1986; Tey \&Fraser, 1994); computational tools (such as hands-on experience with spreadsheet modelling, for example, Bentz, 1979; Curtis, 1990); and, as part of a course of a study (i.e. subjects such as Accounting Information Systems that introduce components of hardware, software and systems analysis, for example, Bhasker, 1982 \& 1983; Ijiri, 1983; McCall, 1988; Armitage \& Boritz 1986).

These classifications of the use of computers in accounting education are consistent with the 1985 American Accounting Association (AAA) and AECC (1990) recommendations to teach accounting more effectively and to provide students with prerequisite computing skills. However, the AAA (1985) suggested that, from an academic viewpoint, the latter of the two objectives would be secondary to the aim of teaching more effectively. Moreover, Albrecht and Sack (2000) recognised that the traditional emphasis of accounting programs on developing technical accounting skills rather than developing a strong understanding of how accounting systems enhance decision-making was one reason why accounting is perceived as less attractive by many prospective students.

Consistent with the AAA view, extant research suggests that the focus of teaching should be on developing accounting knowledge within an information technology environment (e.g. Flaherty, 1979; Paterson, 1986; Suwardy \&

Readers with comments or questions are encouraged to contact the authors via email. 
De Lange, 1998). For example, Flaherty (1979) recommended that development of conceptual knowledge should take precedence over improving technical computing skills. More recently, Suwardy and De Lange (1998) espoused the use of information technology in the delivery of accounting subjects. Based on a student survey, they found that students regarded internet-based teaching as contributing to their learning outcomes.

Most studies that have examined the role of technology in learning have concentrated on the second of the two AAA objectives, namely, development of technical computing skills. For example, in 1994 the ICAA formed a taskforce to investigate the skill requirements for the accounting professional of the $21^{\text {st }}$ century. The report prepared by this body identified skills, such as financial modelling, that will be required by an accountant to function effectively in an information technology environment. More recently, Albrecht and Sack (2000) highlighted the areas in which they believe accounting schools need to focus more heavily to meet industry needs and make accounting more attractive to potential students. Again, the capacity to employ financial modelling and other decision-making tools was emphasised. These computing skills can be taught in Accounting Information Systems courses. Although Orpen and Ferguson (1991) suggested that this second objective is being met, it appears that research has not adequately addressed the first AAA objective. This observation is supported by Boardman and Boardman (1983) who surveyed two-year collegiate institutions in the US and found that, in a majority of cases, computers were not used to enrich principles of accounting such as "basic Debits and Credits". More recently, Suwardy and De Lange (1998) lamented the lack of computer based instruction in accounting classes.

Bromson, Kaidonis, and Poh (1991: 107) expanded the AAA (1985) objectives by suggesting that educators should aim to: develop and reinforce knowledge of accounting concepts; promote understanding of the need for controls in a computerised accounting environment; respond to the needs of the professional environment; and expose students to a commercially available package. The first two of these objectives relate to the first, and seemingly more important, objective identified by the AAA (1985) with the balance relating to the second objective. A general consensus in the literature is that the primary objective of integrating computers into the accounting curriculum should be to develop and reinforce understanding of accounting concepts (Alavi, 1994).

There have been several studies (e.g., Kadonis, 1992; McKeown, 1976; Oglesbee, Bitner \& Wright, 1988) that examine the effect of computers on students' accounting knowledge. These studies have yielded inconclusive and conflicting results. For example, McKeown (1976) performed a controlled experiment and found computer-assisted learning enhanced students' performance. Conversely, Oglesbee et al. (1988) used case studies to assess learning outcomes and reported no significant differences between groups. This latter finding is not surprising and reinforces findings in the general education literature. Russell (1999) for example, cites 350 papers in his website where non significant differences were reported in studies which examined the impact of technology on learning outcomes. Based on the lack of meaningful and confounding results identified in the extant research, and calls for greater use of information technology to enhance learning, the present study evaluates whether the use of an "off-the-shelf" accounting package in learning increases accounting knowledge.

This study extends previous research (e.g., Bromson, Kaidonis \& Poh, 1994; Oglesbee et al., 1988) by evaluating the effect of using a commercially available accounting software package on students' understanding of accounting concepts. The present study is differentiated from these predecessors by the experimental design. This methodology utilises three groups exposed to alternative learning environments with learning outcomes measured using pre- and posttests.

\section{Research Problem}

Most universities have assumed there are benefits in integrating computers into the accounting curricula and much effort has been made to ensure that courses have some kind of computing component (Bronson et al., 1994: 103). For example, most university accounting departments have introduced, in their first-year courses, "hands on" segments that use commercially available accounting software packages. These departments appear to have incorporated these computing components without any pedagogical justification other than to provide students with applied experience of a commercial package. It might be argued that this is an acceptable reason given that many students will be expected to use such a package when they enter the workforce. Moreover, even where more sublime educational rationales are cited 
such as making learning more interesting, rewarding and effective (e.g., Suwardy \& De Lange, 1998), it might well be that course objectives are not being met. For example, a fundamental course objective of preparatory accounting programs is to develop students' understanding of underlying accounting principles such as "debits and credits". Based on prior research (e.g., Orpen \& Ferguson, 1991) it is questionable whether "hands on" experience with a commercial package would reinforce these basic accounting concepts.

McCall (1988) noted consistent scepticism by researchers concerning the educational value of using computers in university courses. For example, Ijiri (1983) identified two potential pitfalls from the introduction of technology into learning. First, the loss of conceptual understanding emanating from over-reliance on computers to the extent that students cannot solve non-routine problems. Second, that reliance on computers engenders in students a perception that output is objective and precise and above question. These two pitfalls are manifested in what Ijiri (1983) termed the development of the para-accountant. He defined the para-accountant as an individual who uses the computer to perform tasks and who accepts output without question. Typically, such a person has little regard to the validity of each step involved in the information systems that generate reports. McCall (1988) added to this concern by emphasising that commercial accounting packages offer little insight into accounting concepts and they might contribute to development of the para-accountant. This argument seems just as relevant today in an environment of integrated information systems as it did in the early 1980s. For example, Wallace $(2001$, p.8) remarked that it was an "injustice" to the accounting field to suggest that technology is replacing much of what we have traditionally covered. She likened this perspective to "...the argument that children no longer need to master the multiplication tables due to calculators" (p.8).

Given concerns regarding the educational value of utilising commercial accounting packages to add value to learning, the aim of the present study is to evaluate whether use of a commercial accounting package improves students' understanding of foundation accounting procedures. To achieve this purpose, the present investigators utilised an experimental design consisting of pre- and post-testing of accounting learning benefits for three distinct treatment groups.

\section{Method}

\subsection{Subjects}

Subjects for this experiment consisted of $20 \%$ of students $(N=150)$ undertaking a first-year accounting subject at a large Australian public university. Participants in the present study were randomly selected from class lists. The group $(n=30)$ that participated in this experiment (divided equally between males and females) were then randomly assigned to three different learning environments: Group one, manual workshop, $n=11$; Group two, commercial accounting package $(C B A), n=11$; and Group three, control group, $n=8$. Due to the small number of computers in the teaching labs (12) the workshop and $C B A$ treatment (these small classes allowed constant interaction between the instructor and subjects) sample sizes were deliberately kept small. Whilst numerically low, the sample size is adequate for statistical inference (Reid, 1991).

\subsection{Measure}

The research instrument consisted of 30 multiple choice questions designed to test the following topics: preparation of worksheet and company accounts; preparation of accounting for inventories; adjusting entries (balance date adjustments); recording transactions; accounting systems; accounts receivables and payables entries; and, accounting for fixed assets. Questions were selected from a database of multiple-choice questions that accompany a commonly used first-year accounting text (Hoggett \& Edwards, 1999). Prior to administering the research instrument, the questionnaire was reviewed by four accounting educators who are familiar with the syllabus of this subject to remove any ambiguities and to improve the clarity of the instrument.

\subsection{Experimental Groups}

CBA Laboratory Session Group (CBA). $C B A$ is a commonly employed commercial accounting package that enables small firms to electronically process accounts receivables and payables, inventories, payroll, fixed assets and many other typical business transactions. It possesses similar features to many other well-known packages such as M.Y.O.B. Premier 
1.0, PeachTree Complete Accounting for Windows 6.0 and Quickbooks Pro 6.0 ${ }^{1}$. Students were given hands-on computer laboratory tuition in use of this package and explanation of the accounting tasks. In an effort to consolidate learning, students were then asked to enter a series of transactions into the General Ledger, Accounts Receivable and Accounts Payable modules. These transactions included balance day adjustments, sales invoices, supplier invoices, cash receipts, cash payments and credit notes. This laboratory session lasted for approximately three hours, with the tutor providing assistance to students' queries and concerns as they worked through the set task.

Manual Workshop Group (Workshop). Students were given a formal classroom instruction to illustrate the same set of transactions as the CBA group. This group recorded all entries manually into journals and ledgers. The tutor used demonstration exercises followed by self-paced transactions recording to facilitate learning. As with the CBA group, the tutor actively responded to students' queries with the session lasting for approximately 3 hours. The objective of the exercise was to ensure that both the CBA and Workshop group were exposed to the same accounting task (or practise set) with differences in learning outcomes attributable to the learning environment.

Control Group. Consistent with scientific experimental design (Wiersma, 1991) this group received no treatment in the period between pre- and post-tests.

\section{Procedure}

Students were randomly allocated to one of the three groups. The procedure then consisted of four stages:

1. $\quad$ All participants were administered an identical test (pre-test)

2. $\quad$ Each group received their treatment (as previously discussed)

3. $\quad$ Subjects completed a post-test that was identical to the pre-test (post-test)

4. Five weeks after the post-test was administered to students, participants completed another identical instrument to determine the durability of student performance (follow-up test).

A summary of the procedure followed for this present investigation is shown in figure 1. It should be noted that participation in the experiment was voluntary without enticement and all groups attended normal classes during the five-week period between the post-test and follow-up test.

Figure 1.: Diagrammatic representation of Research Design.

\begin{tabular}{lcccc}
\hline \multicolumn{5}{c}{ Research Design } \\
Group & $\begin{array}{c}\text { Pre-Test } \\
(1)\end{array}$ & $\begin{array}{c}\text { Treatment } \\
(2)\end{array}$ & $\begin{array}{c}\text { Post-Test } \\
(3)\end{array}$ & $\begin{array}{c}\text { Follow-Up Test } \\
(4)\end{array}$ \\
\hline $\begin{array}{l}\text { Workshop Group } \\
\text { (N=11) }\end{array}$ & $\mathrm{O}_{1 \mathrm{ws}}$ & $\mathrm{X}_{\text {Aws }}$ & $\mathrm{O}_{2 \mathrm{ws}}$ & $\mathrm{O}_{3 \mathrm{ws}}$ \\
$\begin{array}{l}\text { CBA Group } \\
(\mathrm{N}=11)\end{array}$ & $\mathrm{O}_{1 \mathrm{cba}}$ & $\mathrm{X}_{\mathrm{Bcba}}$ & $\mathrm{O}_{2 \mathrm{cba}}$ & $\mathrm{O}_{3 \mathrm{cba}}$ \\
$\begin{array}{l}\text { Control } \\
(\mathrm{N}=8)\end{array}$ & $\mathrm{O}_{1 \mathrm{c}}$ & & $\mathrm{O}_{2 \mathrm{c}}$ & $\mathrm{O}_{3 \mathrm{c}}$ \\
\hline
\end{tabular}

\section{Results and Discussion}

Mean scores and standard deviations for groups on measures over three assessments are shown in Table 1. Analysis of pre-test measures by single factor completely randomised ANOVAs shows non-significant differences. Data were further examined with planned comparisons involving pre-test versus post-test and pre-test versus follow-up data. These comparisons involved 3 (group) $\times 2 \square \square$ time) ANOVAs with repeated measures on one factor (time of measurement). Table 2 shows summaries for ANOVA results. 
Table 1.: Mean Scores and Standard Deviations ${ }^{(a)}$ on each of the Examinations over Three Assessments

\begin{tabular}{|c|c|c|c|c|c|c|}
\hline \multirow{2}{*}{$\begin{array}{ll} & \text { Variable } \\
\text { Total Score }\end{array}$} & \multicolumn{2}{|c|}{ Pretest } & \multicolumn{2}{|c|}{ Posttest } & \multicolumn{2}{|c|}{ Follow-up } \\
\hline & & & & & & \\
\hline Control & 21.63 & $(4.87)$ & 21.13 & $(4.22)$ & 24.13 & $(2.36)$ \\
\hline CBA & 21.91 & (2.98) & 23.00 & $(4.56)$ & 23.55 & $(4.72)$ \\
\hline Workshop & 22.73 & $(3.85)$ & 23.91 & $(2.98)$ & 26.82 & (1.54) \\
\hline \multicolumn{7}{|l|}{ Recording Transactions } \\
\hline Control & 8.00 & $(1.20)$ & 7.88 & $(1.13)$ & 7.75 & $(0.89)$ \\
\hline CBA & 8.36 & $(1.12)$ & 8.46 & $(1.21)$ & 8.00 & $(1.10)$ \\
\hline Workshop & 7.91 & $(0.70)$ & 8.18 & $(0.98)$ & 8.46 & $(0.69)$ \\
\hline \multicolumn{7}{|c|}{$\begin{array}{l}\text { Adjusting Entries (Balance Date Adjust- } \\
\text { ment) }\end{array}$} \\
\hline Control & 3.63 & $(1.19)$ & 3.75 & $(0.89)$ & 4.50 & $(0.76)$ \\
\hline CBA & 3.64 & $(0.92)$ & 4.09 & $(0.94)$ & 4.18 & $(0.98)$ \\
\hline Workshop & 4.36 & $(0.67)$ & 4.27 & $(0.65)$ & 4.36 & $(0.81)$ \\
\hline \multicolumn{7}{|c|}{ Preparation of Worksheets and Company } \\
\hline \multicolumn{7}{|c|}{ Accounts } \\
\hline Control & 2.50 & $(0.93)$ & 2.50 & $(0.76)$ & 3.13 & $(0.64)$ \\
\hline CBA & 3.00 & $(1.10)$ & 3.09 & $(1.58)$ & 3.18 & $(1.17)$ \\
\hline Workshop & 3.00 & $(1.00)$ & 3.90 & $(1.04)$ & 4.46 & $(0.69)$ \\
\hline \multicolumn{7}{|l|}{ Accounting for Inventories } \\
\hline Control & 4.38 & $(0.74)$ & 4.00 & $(1.20)$ & 4.50 & $(0.76)$ \\
\hline CBA & 3.46 & $(1.37)$ & 4.09 & $(1.22)$ & 4.18 & $(1.40)$ \\
\hline Workshop & 3.73 & $(1.42)$ & 3.82 & $(1.17)$ & 4.82 & $(0.60)$ \\
\hline \multicolumn{7}{|l|}{ Accounting Systems } \\
\hline Control & 1.50 & $(0.93)$ & 1.25 & $(0.89)$ & 0.88 & $(0.35)$ \\
\hline CBA & 1.36 & $(0.51)$ & 1.00 & $(0.78)$ & 0.73 & $(0.47)$ \\
\hline Workshop & 1.46 & (0.69) & 1.64 & $(0.67)$ & 1.00 & $(0.00)$ \\
\hline \multicolumn{7}{|c|}{$\begin{array}{l}\text { Accounts Receivables and Payables En- } \\
\text { tries }\end{array}$} \\
\hline Control & 0.88 & $(0.35)$ & 0.75 & $(0.46)$ & 1.88 & $(0.35)$ \\
\hline CBA & 1.00 & $(0.00)$ & 1.09 & $(0.54)$ & 1.82 & $(0.41)$ \\
\hline Workshop & 0.82 & $(0.41)$ & 0.82 & $(0.41)$ & 1.91 & $(0.30)$ \\
\hline \multicolumn{7}{|l|}{ Accounting for Fixed Assets } \\
\hline Control & 0.75 & $(0.89)$ & 1.00 & $(0.93)$ & 1.50 & $(0.76)$ \\
\hline CBA & 1.09 & $(0.83)$ & 1.18 & $(0.75)$ & 1.46 & (0.69) \\
\hline Workshop & 1.46 & $(0.82)$ & 1.27 & $(0.79)$ & 1.82 & $(0.41)$ \\
\hline
\end{tabular}

Total Examination Scores. Analysis of students' pre-test versus post-test total scores (see Table 2) results in a nonsignificant group effect, $F(2,27)=1.74, p=.19$, a significant time effect, $F(1,27)=5.46, p=.02$, and a non-significant group x time interaction, $F(2,27)=.76, p=.48$. Similarly, analysis of students' pre-test versus follow-up data reveals a significant time effect, $F(1,27)=13.25, p=.001$, and non-significant group, $F(2,27)=1.60, p=.22$, and interaction effects, $F(2,27)=1.02, p=.38$ respectively. Analysis of pre-to-post-test and pre-to-follow-up changes within groups are significant only for the workshop group, $t(10)=-2.79, p=.012$, and $t(10)=-3.19, p=.01$.

These findings establish that use of a commercial accounting package does not enhance students' knowledge of basic accounting procedures and concepts. While all groups showed an increase in scores over time, the workshop group was the only group that demonstrated a statistically significant improvement in examination grades. This latter finding provides evidence that traditional teaching methods are more likely to enhance learning outcomes than approaches utilising accounting software packages. 
Table 2: ANOVA Summary Table of Planned Comparisons Involving Pretest Versus Posttest and Pretest Versus Follow-up Data

\begin{tabular}{|c|c|c|}
\hline Variable & $\begin{array}{c}\text { Pretest versus Posttest } \\
\text { F statistic }\end{array}$ & $\begin{array}{c}\text { Pretest versus Follow-up } \\
\text { F Statistic }\end{array}$ \\
\hline \multicolumn{3}{|l|}{ Total } \\
\hline Group & 1.74 & 1.60 \\
\hline Time & $5.46^{*}$ & $13.25 * * *$ \\
\hline Group $\times$ Time & .76 & 1.02 \\
\hline \multicolumn{3}{|c|}{ Recording Transactions } \\
\hline Group & 1.36 & .46 \\
\hline Time & .11 & .01 \\
\hline Group $\times$ Time & .03 & 2.03 \\
\hline \multicolumn{3}{|c|}{ Adjusting Entries (Balance Day Adjustment) } \\
\hline \multicolumn{3}{|l|}{ Group } \\
\hline Time & 2.93 & 1.07 \\
\hline \multirow[t]{2}{*}{ Group $\times$ Time } & $4.47 *$ & $6.43^{*}$ \\
\hline & .23 & 1.84 \\
\hline \multicolumn{3}{|c|}{ Preparation of Worksheet \& Company Accounts } \\
\hline \multicolumn{3}{|c|}{ Group } \\
\hline Time & $4.01 *$ & $5.04 *$ \\
\hline \multirow[t]{2}{*}{ Group $\times$ Time } & 3.10 & $8.61 * *$ \\
\hline & 1.95 & 2.36 \\
\hline \multicolumn{3}{|c|}{ Accounting for Inventories } \\
\hline Group & .02 & 1.34 \\
\hline Time & 1.96 & $5.73 *$ \\
\hline Group $\times$ Time & 1.34 & 1.01 \\
\hline \multicolumn{3}{|l|}{ Accounting Systems } \\
\hline Group & .33 & .55 \\
\hline Time & .82 & $19.71 * * *$ \\
\hline Group $\times$ Time & 2.22 & .22 \\
\hline \multicolumn{3}{|c|}{ Accounting Receivables } \\
\hline Group & 3.08 & .09 \\
\hline Time & 3.88 & $163.84 * * *$ \\
\hline Group $\times$ Time & 1.38 & 1.25 \\
\hline \multicolumn{3}{|c|}{ Accounting for Fixed Assets } \\
\hline Group & .85 & 2.27 \\
\hline Time & 1.11 & $7.22 * *$ \\
\hline Group $\times$ Time & 1.07 & .44 \\
\hline
\end{tabular}

$* \mathrm{p}<.05 . * * \mathrm{p}<.01 . * * * \mathrm{p}<.001$.

Individual Topic Scores. Total examination scores were dissected into individual topic scores to evaluate whether different pedagogical approaches influenced learning outcomes within topics (for example, Recording Transactions). Examination of Table 1 reveals improvement in subtotal scores for the workshop group on Recording Transactions, Preparation of Worksheets and Company Accounts, Accounting for Inventories, Accounts Receivables and Payables Entries, and Accounting for Fixed Assets.

Similarly, for the CBA and control groups, higher raw scores on subtotals are found on Adjusting Entries, Preparation of Worksheets and Company Accounts, Accounting for Inventories, Accounts Receivables and Payables Entries, and Accounting for Fixed Assets. However, Accounting Systems pre-to-follow-up scores deteriorated for all groups.

Notwithstanding these improvements in sub-totals for each group over time, Table 2 shows that Preparation of Worksheets and Company Accounts is the only category that significantly differ on a group basis. Post hoc testing shows that groups differ significantly at post-test, $F(2,27)=7.79, p=.001$. Duncan's tests $(\alpha=.05)$ indicates that, compared to students in the control group, those in the workshop group report significantly higher scores for this particular category. There are non-significant differences between the workshop and CBA groups, and between the control and CBA groups. 
Post hoc testing for Preparation of Worksheets and Company Accounts show that groups differ significantly from pre-test to follow-up, $F(2,27)=8.49, p=.001$. Duncan's tests indicate that, compared to students in the control and CBA groups, those in the workshop group report significantly higher scores for this particular category. There are nonsignificant differences between control and CBA groups.

Analysis of pre-to-post-test changes within groups are significant only for the workshop group, $t(10)=-3.07$, $p=.007$. Conversely, analysis of pre-to-follow-up changes within groups are significant for both the workshop, $t(10)=-4.28, p=.002$, and control, $t(7)=-2.38, p=.049$, groups.

Adjusting Entries is the only category where the CBA group outperformed the workshop group (see Table 1). This finding is not surprising given that this category tests balance date adjustments. As noted previously, these types of entries require students to input both sides of the transaction into the commercial package (unlike the other areas tested) and therefore it is likely that use of such a package would, improve students' understanding of these types of procedures and concepts.

\section{Comparison of Results with Theory and Research}

As indicated in the Introduction section of this paper, extant research (e.g., Curtis, 1990) into the introduction of technology into learning has focussed primarily on whether this process provides students with the prerequisite computing skills. A review of the literature reveals that there are few studies (examples are Bromson et al,. 1994, Kaidonis, 1992) that have specifically addressed the major issues examined in this study. While Bromson et al. (1994) highlighted possible research questions to be addressed in regard to the impact of commercial packages on student understanding it did not empirically evaluate these questions. Kaidonis (1992) evaluated the effects of a commercially available package on student understanding of accounting concepts. She reported that "...there is likely to be some positive influence of a five week computerised accounting section on the understanding of specific concepts" (p.6). However, it should be noted that there was no control group employed for this study and so Kaidonis concluded that "...these results should only be seen as encouraging rather than conclusive" (p.6). The present study, using an experimental design, found that adoption of a commercially available computer package does not significantly enhance students' knowledge of basic accounting procedures and concepts. This finding should be viewed in light of the AAA (1985) and the ICAA (1994) recommendations that use of computers in accounting education should emphasise the objective of teaching more effectively rather than the aim of providing students with technical computing skills.

The findings of the study should also be viewed in light of studies examining student perceptions of the impact of information technology on the delivery of accounting programs such as Beaman and Richardson (1993) and Suwardy and De Lange (1998). These studies found that students preferred to be abreast of changing technology and its implementation into the classroom. They also regarded that exposure to information technology improved their future employment prospects.

There are a number of limitations to our study. First, the sample size $(n=30)$ is small. This small sample size could have the effect of reducing the statistical power and increasing the type II error rate (Kazdin, 1980). Second, students involved in this study were from one subject offered in an accounting course at a large Australian university. Thus, findings may not be generalisable to all accounting students. Third, there might be variables apart from the treatment that impact on examination scores, particularly for the follow-up test (e.g., quality of teaching, different learning styles). Further, some commentators (see, Gros and Spector, 1994) have argued that the use of experimental methods in the social sciences are not justified as differences in measured outcomes may be attributable to other plausible explanations. However, features of the research design were voluntary participation and random allocation of students to groups in an effort to mitigate the effects of many of these factors (e.g., gender, intelligence, learning style differences, past academic achievement, and motivation).

\section{Conclusion}

This study has important implications for accounting education. Findings indicate that use of a commercial accounting package for educational purposes is not superior to traditional teaching approaches. Thus, these findings raise a question as to why use of such packages are integrated into accounting syllabi without initial evaluation of their teach- 
ing usefulness. This is particularly concerning given the emphasis by bodies such as the AAA and the ICAA on ensuring such innovations do enhance accounting teaching effectiveness, and the concerns of academics such as Ijiri (1983) and Suwardy and De Lange (1998) regarding the educational value of using computers in accounting education. Introduction of such packages does not appear to enhance understanding of accounting procedures and concepts. Traditional teaching approaches might be more effective in teaching these fundamentals. However, if universities introduce these packages as part of a course as a means of providing students with experiences that enhance their employment prospects then their use might be justified.

\section{Suggestions for Future Research}

At least three worthy avenues for future research emanate from this study. First, it would be interesting to see if similar findings apply across diverse countries, cultures, and educational settings. Second, it is possible that the learning benefits from use of computer packages may be greater for more mature students or for graduate students. Third, contact with these packages may result in favourable employment outcomes for graduates. It follows that a study comparing the future careers of those students with exposure to these packages with a control group would be insightful.

\section{Acknowledgements}

The authors would like to thank Graeme Dean, George Tanewski, and participants at both the 2002 AAA National Meeting in Atlanta and the 2001 AAANZ Meeting for their useful comments on earlier drafts of this paper.

\section{References}

1. Alavi, Maryam, "Computer-Mediated Collaborative Learning: An Empirical Evaluation", MIS Quarterly, Vol. 18, No. 2, pp. 159-174, 1994.

2. Albrecht, Steve and Robert, Sack, Accounting Education: Charting the Course through a Perilous Future, Vol. 16, American Accounting Association Accounting Education Series, American Accounting Association, Sarasota, FL., 2000.

3. American Accounting Association, Committee on Integrating the Computer into the Managerial/Cost Curriculum, Integrating the Computer into the Managerial/Cost Curriculum: A Resource Manual, American Accounting Association, Sarasota, FL., 1985.

4. Accounting Education Change Commission, "Objectives of Education For Accountants: Position Statement Number One", Issues in Accounting Education Vol. 5, No. 2, pp. 307-312, 1990.

5. American Accounting Association Committee on the Future Structure, Content and Scope of Accounting Education (The Bedford Committee), "Future Accounting Education: Preparing for the Expanded Profession," Issues in Accounting Education Vol. 1, No. 1, pp. 168-95, 1986.

6. Armitage, Howard M. and J. Efrim Boritz, "Integrating Computers into the Accounting Curriculum," Issues in Accounting Education, Vol. 1, No. 1, pp. 87-98, 1986.

7. Beaman, Ian and Richardson, William, "Student Attitudes to the Use of the CBA Accounting Package in First Year Accounting." Syme Department of Accounting Working Paper Series, Monash University, Melbourne, Australia, 1993.

8. Bentz, William F., "Computer Extended Reciprocal Allocation Methods", The Accounting Review, Vol. 54, No. 3, pp. 595-603, 1979.

9. Biggs, John. B. “Teaching for Quality Learning at University”, United Kingdom, Society for Research into Higher Education and Open University Press, 1999.

10. Birkett, William, "Task Force on Education," Australian Accountant, October, pp. 54-58, 1987.

11. Boardman, Eunice G. and Boardman, C.C., "The Status of the Computer in Principles of Accounting at TwoYear Collegiate Institutions, 1981-82," in Collected Abstracts of the American Accounting Association's Annual Meeting, American Accounting Association, Sarasota FL. pp. 56-57, 1983.

12. Bromson, G., Kaidonis, Mary A. and Poh, Paul, "Accounting Information Systems and Learning Theory: An Integrated Approach to Teaching," Accounting Education, Vol.3, No.2, pp. 101-114, 1994.

13. Collins, J. Carlton, "How to Select the Right Accounting Software", Journal of Accountancy, August, pp. 6169, 1999. 
14. Curtis, Graham, "Computing in Accounting Education", Management Accounting, September, pp. 54-59, 1990.

15. Flaherty, Richard E., "The Core of the Curriculum for Accounting Majors", American Accounting Association Discussion Paper, American Accounting Association, Sarasota, FL., 1979.

16. Flanagan, Jack. and Juchau R., "The Core of the Curriculum for Accounting Undergraduates - An Australian Study," Accounting and Finance, Vol 23, No 2, November, pp. 67-80, 1983.

17. Gerrard, M., Bromson, G. and Kaidonis, Mary A., Computerised Accounting Using Sybiz, Prentice-Hall, Australia, 1989.

18. Helmi, Medhat A., "Integrating the Microcomputer into Accounting Education - Approaches and Pitfalls," Issues in Accounting Education, Vol. 1, No. 1, pp. 102-111, 1986.

19. Hoggett, John R. and Edwards, L., Accounting in Australia, $4^{\text {th }}$. Edition, John Wiley \& Sons, Brisbane, Australia, 1999.

20. Ijiri, Yuji, "New Dimensions in Accounting Education: Computers and Algorithms," Issues in Accounting Education, pp. 168-173, 1983.

21. Institute of Chartered Accountants in Australia, "Chartered Accountants in the $21^{\text {st }}$. Century", White Paper, pp. 2-4, 1994.

22. Kaidonis, Mary. A. "The Effect of Computerised Accounting on the Understanding of Accounting Concepts: Some Preliminary Results," Australian and New Zealand Accounting Academics Annual Meeting, Palmerston North, New Zealand, 1992.

23. Kazdin, Alan E., Research Design in Clinical Psychology, Harper and Row, New York, NY, 1980.

24. McCall, D., "Integrating Computers into Accounting Education," Occasional Paper, Deakin University, December, No 106, pp. 1-26, 1988.

25. McKeown, J.C., "Computer-Assisted Instruction for Elementary Accounting", The Accounting Review, Vol. 51, No. 1, pp123-30, 1976.

26. Oglesbee, T.W., Bitner, L.N. and Wright, G.B., "Measurement of Incremental Benefits in Computer Enhanced Instruction", Issues in Accounting Education, Vol 3, No 2, pp. 365-77, 1988.

27. Orpen, Christopher and Ferguson, Colin, "The Attitudes of Accounting Students to Working with Computers: A Preliminary Study," Accounting and Finance, November, Vol 31, No 2, pp. 112-119, 1991.

28. Paterson, Helena M., "The Use of Fourth Generation Languages for Computer Assisted Learning in Management Accounting", Proceedings of the Fourth Annual Computer Assisted Learning in Tertiary Education Conference, Adelaide, pp. 192-206, 1986.

29. Reid, S., Working with Statistics, Polity Press, Cambridge, UK, 1991.

30. Russell, Thomas L., "The No Significant Difference Phenomenon", Available at: http//tenb.nbcc.nb.ca/phenom/, 2001.

31. Spector, B. and Gros, M., "Evaluating Automated Design Systems: A Complex Problem", Educational Technology, Vol. 34, No. 5/6, pp 37-46, 1994.

32. Suwardy, Themin. and De Lange, Paul. A., "Delivery of Accounting Subjects via the Internet: Student Perceptions", Accounting Research Journal, Vol.11, No.1, pp. 327-40, 1998.

33. Teh, George P. and Fraser, Barry J., "An Evaluation of Computer-Assisted Learning in Geography in Singapore", Australian Journal of Educational Technology, Vol. 10, No.1, pp. 55-66, 1994.

34. Wallace, Wanda, "Accounting Education: Iceberg or Ice Cube”, Accounting Today, January 29 - February 11, pp. 8-9, 2001.

35. Wiersma, William, Research Methods in Education, $5^{\text {th }}$. Edition, Allyn \& Bacon, Boston, MA., 1991.

\section{Endnotes}

1 Collins (1999) provides a useful comparison of the features of many commercial accounting packages currently available for small to medium-size firms. 
Notes 


\section{DO NOT PRINT THIS PAGE}

1 Collins (1999) provides a useful comparison of the features of many commercial accounting packages currently available for small to medium-size firms. 